\title{
Basic Needs as a Predictors of Prospective Teachers' Self-actualization
}

\author{
Ali Arslan \\ Educational Faculty, Bulent Ecevit University, Turkey
}

Copyright $(2017$ by authors, all rights reserved. Authors agree that this article remains permanently open access under the terms of the Creative Commons Attribution License 4.0 International License

\begin{abstract}
The purpose of this study is to compare the predictive power of prospective teachers' basic needs on self-actualization. This is a correlational research which is one of the descriptive research methods. The study was conducted on 1033 prospective teachers studying in Bulent Ecevit University Eregli Faculty of Education in the spring term of the academic year of 2013-2014. Data were collected with "self-actualization scale" which is subscale of "Healthy Life Style Behaviour Scale" and "University Students' Basic Needs Scale". Pearson product-moment correlation coefficient technique and stepwise-regression analysis were used to analyze the data. As a result of the study, it has been identified that the most effective factor on prospective teachers' self-actualization is the fun need which is one of the sub-dimension of basic needs.
\end{abstract}

Keywords Motivation, Basic Needs, Self-actualization, Prospective Teacher

\section{Introduction}

Human beings have been trying to understand the factors that affects behavior in order to improve themselves and to provide better training for others. The motivation is one of factors which is effecting human behaviors. Motivation is goal directed and internal force that actives, enegizes, directs, and sustains behavior ([19]; [20]; [23]; [26]). As a result of that aim of understanding, there comes two views in psychology; "Drive-reduction" and the other "force for growth" [5]. Drive theory is advocated by behaviourists while force for growth view is advocated by humanist psychologists. Drive is motivational force which directs organisms into action. Drive reduction realizes when obtained reinforcement to satisfy needs. Acoording to humanistic psychologists, the most important motive that govern the behavior of people is the motive of self-actualization [25].
The individual needs many things from birth. It is very important to know what these needs are in order to understand the human nature. As a product of this effort, A. Maslow and W. Glasser have put forward theories about how an individual understands needs and how these needs can be met. According to Glasser's choise theory[12], survival, love and belonging, power, freedom, and fun are the five basic needs that we have. Glasser believes that we need to understand the underlying causes of our behavior and these causes are also stored in our genes. All creatures are genetically programmed to survive. Survival needs are physiologycal needs include food, shelter, clothing, safety. This coincide with survival and safety needs in Maslow's hierarcy of needs. Other four needs are psychological ones. Love and belonging need include relationship with others, feeling of belonging to community and feeling of affection. This need is the most difficult need to satisfy because the involvement of other people is necessary for meeting this desire. The need to belong is innately (universal). All people must have the need to belong to some degree. Because satisfaying later needs depends on love and belonging needs. The lack of it develops severe deprivation, burnout and variety of ill affects ([3]; [10]). This need coincide with relatedness need in the self-determination theory. Power need includes sense of self-worth, feeling of competence to achieve a task and to be recognised for this reason. This need brings out in shape of proving self-sufficiency in a subject. Power need refers to competence need in the self-determination theory. Freedom need includes need for autonomy and making choise among different options. To support autonomy of people enhances their internal motivation, creativity, self-motivation, confidence, interest, positive well-being, life satisfaction, and vitality while the absence of this support weakens this properties ([8]; [15]). This need resemble autonomy need in the self-determination theory. Self-determination theory argues that, autonomy competence, and relatedness are psychological needs fostering self, growth, integrity and, well-being ([7]; [24]). Fun need includes playing, laughing needs. According to Glasser, fun need is associated with 
learning. Because while human play, they learn important things. Although all needs effect subject well being, freedom and fun needs are the most effective needs on it [29].

Basic needs must be satisfied in constructively ways. If people can't manage this, they may engage in destructive psychological processes and actions to meet these needs [28]. The assumption that after $100 \%$ of the need at low level is met, we proceed to the need at high level is wrong. Even the partial fulfillment of the needs is enough to feel the need at high level. $85 \%$ of physiological needs, $70 \%$ of safety needs, $50 \%$ of the love and belonging needs, $40 \%$ of the esteem needs and $10 \%$ of the self-actualization needs are met [17]. Even if an individual meets the physiological, safety, love and belonging, self-esteem needs to a certain extent, he faces with unrest and dissatisfaction and he says that until the need for presenting a life style which is suitable for his nature and his background is met and this unrest and dissatisfaction are eliminated, this unrest and dissatisfaction will continue. The ultimate need is the need for self-actualization. The need for individual self-actualization expresses the desire to mobilize their potential, their unique characteristics and, their abilities. Even if the fulfillment of the need for self actualization changes from person to person, this means the desire for activating the person's own potential, his own characteristics and his own abilities [18].

The need for self actualization is highest need to be satisfied. Before higher order needs, lower order needs must be satisfied appropriately and adequately. So, this research aimed to investigate how much basic needs are effective on higher order needs [21]. Thanks to the teachers whose self-actualization level is high, the quality of the outcomes revealed as a result of the educational system may be higher. It is aimed in the faculty of education first that the prospective teachers may become teacher realizing themselves. When the effect of the basic needs on the self actualization is determined, the activities for satisfying these basic needs can be made. Curricula and learning environments may be arranged for this reason. The aim of this study is to reveal the effects of the basic needs of the prospective teachers on the self-actualization.

\section{Materials and Methods}

\subsection{Design}

The correlational method was used in this study. The correlational research explores relations between variables (Creswell, 2012). This study investigated whether there was a relationship between prospective teachers' scores of meeting the basic needs and scores of self- actualization.

\subsection{Participants}

The participants of the study consisted of 1033 prospective teachers between the ages of 18- 24 years studying from the Bulent Ecevit University Eregli faculty of education in the spring term of 2013-2014. To be enhance generelizability of results, prospective teachers in all departments of faculty was included to study. The participants constituted $34 \%$ male and $66 \%$ female; $34,6 \%$ sophomore, $27,4 \%$ sophosticated, $21,4 \%$ juniors and $16,7 \%$ seniors.

\subsection{Instruments}

The instruments of the study were University Students' Basic Needs Scale" and "Self-actalization Scale" is subscale of "Healthy Life Style Behavior Scale".

\subsubsection{University Students' Basic Needs Scale}

The scale was developed by Türkdoğan and Duru [30] in order to identify the level of prospective teachers' meeting the basic needs. Pilot study of scale were conducted on a total of 671 Pamukkale University students from different departments of the Faculty of Education. Analysis indicated that the scale consists of 33 items and has a five factor. The students rated items on a 7-point likert scale ranging from 1 (strongly disagree) to 7 (strogly agree). The informations about sub-factors of scale were presented in table 1 .

Table 1. Sub-factors of University Students' Basic Needs Scale

\begin{tabular}{|c|c|c|c|c|c|c|}
\hline Factor & $\mathbf{n}$ & $\begin{array}{c}\text { Interval of } \\
\text { Factor } \\
\text { Loadings }\end{array}$ & $\begin{array}{c}\text { Explained } \\
\text { Variance }\end{array}$ & $\boldsymbol{\alpha}$ & $\begin{array}{c}\boldsymbol{\alpha} \text { in this } \\
\text { study }\end{array}$ & Sample Items \\
\hline Fun & 9 & $0,57-0,73$ & $\% 22,23$ & 0,84 & 0,82 & $\begin{array}{c}\text { I can spend enough time to fun social activities (concerts, } \\
\text { theater, show, etc.) in my life. }\end{array}$ \\
\hline Freedom & 9 & $0,41-0,71$ & $\% 8,53$ & 0,78 & 0,70 & I have the autonomy and independence I want in my life. \\
\hline Power & 6 & $0,50-0,74$ & $\% 6,21$ & 0,77 & 0,69 & $\begin{array}{c}\text { The people around me consult me on important issues and } \\
\text { value my thoughts }\end{array}$ \\
\hline $\begin{array}{c}\text { Love and } \\
\text { Belonging }\end{array}$ & 4 & $0,59-0,79$ & $\% 5,13$ & 0,76 & 0,82 & $\begin{array}{c}\text { In my life, I have true friends whom I can sincerely share my } \\
\text { feelings and thoughts }\end{array}$ \\
\hline Survival & 5 & $0,60-0,82$ & $\% 5,88$ & 0,77 & 0,64 & $\begin{array}{c}\text { I feel safe and secure in the environment I live in } \\
\text { (university, home, etc.) }\end{array}$ \\
\hline
\end{tabular}


According to reliability table, it is interpreted that Cronbach $(\alpha)$ internal consistency coefficient are sufficient for this study.

\subsubsection{Self-actalization Scale}

Self-Actualization scale which was used to identfy the level of self-actualization of the prospective teachers, developed in 1987 by Pender, was sub-scale of "Healthy Lifestyle Behaviors Scale" that adapted by Esin [11] into the Turkish language. The scale consisted of 13 items and is 4- point likert scale. The Cronbach's alpha internal consistency coefficient of the scale was calculated as 0,77 in the translation study and as 0,84 in this study.

\subsection{Analysis}

The normality value of data were examined to decide analysis method. The skewness and kurtosis values of data were between -1 and +1 . So, Pearson product-moment correlation coefficient was conducted to examine relation between basic needs scores and self-actualization scores. Also, stepwise regression analysis was conducted to examine the effect of the prospective teachers' basic needs on self-actualization.

\section{Findings}

Firstly, for the purpose of the study, the correlation between the basic needs scores of prospective teachers and their self-actualization scores has been examined. So, Pearson product-moment correlation coefficient was conducted for this reason. The findings are presented in the table 2 .

Table 2 suggested that there was a significant correlations between the self-actualization scores of the prospective teachers and the basic needs scores at the level of 0.01 . The highest correlations with self-actualization scores of prospective teachers was realized at the fun sub-dimension. There was a positive, moderate and significant correlation between these variables $(\mathrm{r}=0,463 ; \mathrm{p}<0,01)$. In addition, there was a significant correlation between prospective teachers' self-actualization scores and the need for power ( $\mathrm{r}$ $=0,410 ; \mathrm{p}<0,01)$, freedom $(\mathrm{r}=0,376 ; \mathrm{p}<0,01)$, love and belonging $(r=0,344 ; p<0,01)$, while the there was weakest correlation between prospective teachers' self-actualization scores and survival needs scores $(r=0,082, p<0,01)$.

Table 2. Correlations between basic needs and self-actualization

\begin{tabular}{|c|c|c|c|c|c|c|}
\hline & Sur & LoBe & Pow & Free & Fun & Self-Ac \\
\hline Sur & 1,000 & - & - & - & - & - \\
\hline LoBe & $0,117^{* *}$ & 1,000 & - & - & - & - \\
\hline Pow & $0,079^{*}$ & $0,298^{* *}$ & 1,000 & - & - & - \\
\hline Free & $0,105^{* *}$ & $0,327^{* *}$ & $0,274^{* *}$ & 1,000 & - & - \\
\hline Fun & $0,098^{* *}$ & $0,429^{* *}$ & $0,357^{* *}$ & $0,433^{* *}$ & 1,000 & - \\
\hline Self-Ac & $0,082^{* *}$ & $0,344^{* *}$ & $0,410^{* *}$ & $0,376^{* *}$ & $0,463^{* *}$ & 1,000 \\
\hline M & 4,50 & 6,07 & 5,41 & 4,93 & 5,27 & 3,09 \\
\hline SD & 1,31 & 1,10 & 0,98 & 0,93 & 1,09 & 0,48 \\
\hline Min & 1,00 & 1,00 & 1,00 & 1,00 & 1,00 & 1,00 \\
\hline Max & 7,00 & 7,00 & 7,00 & 7,00 & 7,00 & \\
\hline
\end{tabular}

${ }^{*} \mathrm{p}<0,05 ;{ }^{* *} \mathrm{p}<0,01$; Fun: Fun; Free: Freedom; Pow:Power; Sur: Survival; LoBe: Love and Belonging; Self-Ac: Self-Actualization.

Table 3. Stepwise and Hierarchical Regression Analysis Results

\begin{tabular}{|c|c|c|c|c|c|c|c|c|}
\hline Model & Predictors & $\mathrm{R}$ & $\begin{array}{c}\mathrm{R}^{2} \\
\text { (Stepwise } \\
\text { approach) }\end{array}$ & $\begin{array}{c}\mathrm{R}^{2} \\
\text { (Hierarachical } \\
\text { approach) }\end{array}$ & $\begin{array}{c}\mathrm{R}^{2} \text { Change } \\
\text { (Stepwise } \\
\text { approach) }\end{array}$ & $\begin{array}{c}\mathrm{R}^{2} \text { Change } \\
\text { (Hierarachical } \\
\text { approach) }\end{array}$ & $\mathrm{F}$ & $\mathrm{p}$ \\
\hline 1 & Fun & 0,463 & 0,215 & 0,215 & 0,215 & 0,215 & $275,918^{*}$ & 0,000 \\
\hline 2 & $\begin{array}{c}\text { Fun } \\
\text { Power }\end{array}$ & 0,534 & 0,285 & 0,273 & 0,070 & 0,058 & $201,157^{*}$ & 0,000 \\
\hline 3 & $\begin{array}{c}\text { Fun } \\
\text { Power } \\
\text { Freedom }\end{array}$ & 0,556 & 0,309 & 0,309 & 0,024 & 0,036 & $150,039^{*}$ & 0,000 \\
\hline $\begin{array}{c}\text { Fun } \\
\text { Power } \\
\text { Freedom } \\
\text { Love and } \\
\text { Belonging } \\
\text { Fun } \\
\text { Power } \\
\text { Freedom } \\
\text { Love and } \\
\text { Belonging } \\
\text { Survival }\end{array}$ & 0,564 & 0,318 & 0,318 & 0,010 & 0,010 & $117,593^{*}$ & 0,000 \\
\hline & 0,564 & - & 0,318 & - & 0,000 & 0,169 & 0,681 \\
\hline
\end{tabular}

$\mathrm{p}<0,001$; Dependent variable: Self-actualization; Independent variable: Fun, power, freedom, love and belonging. 
Stepwise regression analysis was conducted to determine the predictive power of basic needs of prospective teachers on self-actualizations. The self-actualization is the dependent variable and the basic needs are the independent variable in present study.The findings are presented in table 3.

Table 3 indicates that fun need is the most powerful predictor of self-actualization scores of the prospective teachers. This factor alone predicted $21,5 \%$ of prospective teachers' self-actualization scores $\left(\mathrm{F} \quad\right.$ Change $_{(1,1010)}=$ $275,918 ; \mathrm{p}<0,001)$. The power need predicted $7 \%$ of total variance of prospective teachers' self-actualization scores ( $F$ Change $\left._{(1,1009)}=99,490 ; p<0,001\right)$. The other significant predictors of self-actualization were freedom need and love and belonging need. These needs subsequently predicted $2,4 \%$ (F Change $\left.{ }_{(1,1008)}=34,461 ; \mathrm{p}<0,001\right)$ and $1 \%(\mathrm{~F}$ Change $\left.{ }_{(1,1007)}=14,310 ; p<0,001\right)$. These four factors, which constitute the basic needs, predicted $31.8 \%$ of the total variance in self-actualization $\left(\mathrm{F}_{(4,1007)}=117,593 ; \mathrm{p}<0,001\right)$. The only factor that had no significant effect on the scores of self-actualization of prospective teachers is the survival need.

\section{Conclusion and Discussion}

The present study examined the effect of prospective teachers' basic needs on their self-actualization. It can be concluded that the fun, power, freedom, and love and belonging needs which are among the basic needs of the prospective teachers had a significant effect on the self -actualization. But, only survival need did not have a significant effect on the self-actualization of prospective teachers.

It was found out the most influential need on the self -actualization level of the prospective teachers was fun. Intriguing, enjoyable, interesting and valuable activities influence motivation ([33]; [34]). The self-actualizing people have sense of humor personality [18]. So, satisfaying the fun need may feed self-actualization. Harackievcz [12] and Ryan, Mims and Coesner [22] found that there was a positive moderate and significint correlation between self-reported interest (enjoyment) and intrinsic motivation. Therefore, for the prospective teachers, the process of teaching and learning may be ensured to be fun and they may be ensured to see whether the students may learn. The fact that individuals realizing themselves has a good sense of humor according to Maslow has the characteristics supporting this result. Since the individuals having an entertaining personality are at peace with themselves, they may criticize themselves easily and they may face with their own abilities. Therefore, they will have the opportunity to see their negative sides and improve them. In common with this result, Turkdogan [28] also reached the conclusion that the fun need was the strongest factor on the subjective well-being of the university students.
It was revealed that the second strongest basic needs on the self-actualization level of the prospective teachers was power need. Power is equivalent to obtaining respect and status in the hierarchy of needs of Maslow. When individuals own a certain status and power and own a prestigious position in the society, they will own broader opportunities. They may ensure to realize themselves by using these opportunities and means. In addition, since owning a high status in the society will increase the self-confidence and the self -respect of the individual, their self -actualization will be easier in this situation. Cihangir-Cankaya [5] and Turkdogan [29] have found the power and the belief of self-efficacy was revealed to have a significant effect on the subjective well-being of the prospective teachers. Bandura ([1]; [2]) asserted the the self-efficacy beliefs determine the motivation levels of people.

In present study, it was found out that the satisfaction level of the need for freedom of the prospective teachers had a significant effect on their self-actualization. It may imply that the university environment is free and the prospective teachers feel themselves free have an important place on their self-actualization. The fact that the individuals feel themselves free, ensure them to show their abilities easily and to develop them. This helps the individuals realize themselves. Self- actualizing people are described as relatively spontaneous [18]. So, satisfaying the freedom need may develops self-actualization. Karahan, Sardogan, Ozkamali and Dicle [14] found a positive relationship between the democratic inclination of the prospective teachers and their self-actualization, Turkdogan [29] reached the conclusion that the need for freedom was a strong factor on the subjective well being of the university students. In the studies carried out by Cihangir-Cankaya [5], it was found that the need for autonomy had a positive effect on the life satisfaction and the self- respect of the university students. Similarly, Kasser and Ryan [15] found that autonomous support of people were positively correlated with positive well- being, vitality and life satisfaction. Autonomous support accounted for $17 \%$ of variance in positive well- being, $\% 23$ of variance in vitality, and $\% 32$ of variance in life satisfaction. Sheldon and Bettencourt [27] reported that there was positive medium and significant correlation between personal autonomy and positive affect, commitment and intrinsic motivation.

To meet the needs for love and belonging of the prospective teachers has also a positive effect on their self-actualization. The self-actualizing people have powerfull interpersonal relations [18]. So, satisfying love and belonging needs may support self-actualization. Also, quality of relatedness to people is positively associated with positive well- being and life satisfaction [15]. Therefore, the fact that the prospective teachers love the universities, departments they study and their jobs and they feel that they belong in the institution they work help them realize themselves. In common with this study Unsar, Kostak, Kurt 
and Erol [31] also found out that the nurses who love their jobs more have a higher level of self -actualization compared to the nurses who love their jobs less. Also, Sheldon and Bettencourt [27] reported that there was positive medium and significant correlation between interpersonal relatedness and positive affect, commitment and intrinsic motivation.

Chen, et al [4] researched correlation between psychological need satisfaction (autonomy, relatedness, competence) and psychological well-being (life satisfaction, vitality, depressive symptoms). They have found there was positive moderate and significant correlation between psychological need satisfaction (autonomy, relatedness, competence) and life satisfaction, vitality; positive moderate and significant correlation between depressive symptoms. Similarly, Van den Broeck, Vansteenkiste De Witte and Lens [32] found out that there was a positive medium, and significant correlation between the basic need satisfaction and the need for competence and belonging, there was a positive, high and significant correlation with the need for autonomy. Decy, et al [9] found that need satisfaction was posivitely correlated with generel self-esteem and participation and negatively correlated with anxiety.

The need which did not have a significant effect on the self -actualization of prospective teachers should be studied further and analyze why survival need is not significant, whereas survival need is the basic of all needs.

\section{REFERENCES}

[1] Bandura, A. (1989). Human agency in social cognitive theory. American psychologist, 44(9), 1175.

[2] Bandura, A. (1997). Self-efficacy: The exercise of control. Macmillan.

[3] Baumeister, R. F., \& Leary, M. R. (1995). The need to belong: desire for interpersonal attachments as a fundamental human motivation. Psychological bulletin, 117(3), 497.

[4] Chen, B., Vansteenkiste, M., Beyers, W., Boone, L., Deci, E. L., Van der Kaap-Deeder, J., \& Ryan, R. M. (2015). Basic psychological need satisfaction, need frustration, and need strength across four cultures. Motivation and Emotion, 39(2), 216-236.

[5] Cihangir-Çankaya, Z. (2009). Özerklik desteği, temel psikolojik ihtiyaçların doyumu ve öznel iyi olma: Öz belirleme kuramı. Türk Psikolojik Danışma ve Rehberlik Dergisi, 4 (31), 23-31.

[6] Creswell J. W. (2012). Educational research planning conducting and evaluating quantitative and qualitative research. ( $4^{\text {th }}$ edition). Pearson.

[7] Deci, E. L. \& Ryan, R. M. (1985). Intrinsic motivation and self-deternination in human behaviour. NY: Plenum.

[8] Deci, E. L., \& Ryan, R. M. (1987). The support of autonomy and the control of behavior. Journal of personality and social psychology, 53(6), 1024.
[9] Deci, E. L., Ryan, R. M., Gagné, M., Leone, D. R., Usunov, J., \& Kornazheva, B. P. (2001). Need satisfaction, motivation, and well-being in the work organizations of a former eastern bloc country: A cross-cultural study of self-determination. Personality and social psychology bulletin, 27(8), 930-942.

[10] Demirdag, S. (2016). The relationship between faculty members school culture and burnout levels based on the perceptions of teacher candidates. E-International Journal of Educational Research, 7(3), 49-62.

[11] Esin, N. (1997). Endüstriyel alanda çalışan işçilerin sağlık davranışlarının saptanması ve geliştirilmesi. Yayınlanmamış Doktora Tezi. İstanbul Üniversitesi Sağlık Bilimleri Enstitüsü, İstanbul.

[12] Glasser, W. (1998). Choice theory New York: Harper Collins.

[13] Harackiewicz, J. (1979). The effects of reward contingency and performance feedback on intrinsic motivation. Journal of Personality and Social Psychology, 37. 1352-1363.

[14] Karahan, T.F., Sardoğan, E. M., Özkamalı, E., \& Dicle, N. A. (2006). Öğretmen adaylarında demokratik tutum, nevrotik eğilimler ve kendini gerçekleştirme. Hacettepe Üniversitesi Ĕ̈itim Fakültesi Dergisi, 30, 149-158.

[15] Kasser, V. G., \& Ryan, R. M. (1999). The Relation of psychological needs for autonomy and relatedness to vitality, well - being, and mortality in a nursing home. Journal of Applied Social Psychology, 29(5), 935-954.

[16] Kuzgun, Y. (1972). Kendini gerçekleştirme. Ankara Üniversitesi Dil ve Tarih-Coğrafya Fakültesi Felsefe Bölümü Dergisi, 10(1).

[17] Maslow, A. H. (1943). A theory of human motivation. Psychological review, 50(4), 370.

[18] Maslow, A. H.(1970). Motivation and personality (2). J. Fadiman, \& C. McReynolds (Eds.). New York: Harper \& Row.

[19] Moreno, R. (2010). Educational Psychology, New Jersey: John Wiley \& Sons Inc.

[20] Ormrod, J. E. (2006). Essentials of Educational Psychology, Upper Saddle River: Pearson Education.

[21] Petri, H. L. (1986). Motivation: Theory and research. Belmont: Wadsworth.

[22] Ryan, R. M., Mims, V., \& Koestner, R. (1983). Relation of reward contingency and interpersonal context to intrinsic motivation: A review and test using cognitive evaluation theory. Journal of Personality and Social Psychology, 45, 736-750.

[23] Ryan, R. M., \& Deci, E. L. (2000a). Intrinsic and extrinsic motivations: Classic definitions and new directions. Contemporary educational psychology, 25(1), 54-67.

[24] Ryan, R. M., \& Deci, E. L. (2000b). The darker and brighter sides of human existence: Basic psychological needs as a unifying concept. Psychological Inquiry, 11(4), 319-338.

[25] Schunk, D. H. (1990). Introduction to the special section on motivation and efficacy. Journal of Educational Psychology, 82, 3-6. 
[26] Schunk, D. H. (2000). Learning theories: An educational perspective. New Jersey: Printice Hall Inc.

[27] Sheldon, K. M., \& Bettencourt, B. (2002). Psychological need satisfaction and subjective well-being within social groups. British Journal of Social Psychology, 41(1), 25-38.

[28] Staub, E. (1999). The roots of evil: Social conditions, culture, personality, and basic human needs. Personality and Social Psychology Review, 3(3), 179-192.

[29] Türkdoğan, T. (2010). Üniversite öğrencilerinde temel ihtiyaçların karşılanma düzeyinin öznel iyi oluş düzeyini yormadaki rolü. Yayınlanmamış Yüksek Lisans Tezi. Pamukkale Üniversitesi Sosyal Bilimler Enstitüsü, Denizli.

[30] Türkdoğan, T.,\& Duru, E. (2012) Üniversite öğrencileri temel ihtiyaçlar ölçeği'nin (ÜÖTïÖ) geliştirilmesi: Geçerlik ve güvenirlik çalışması. Pamukkale Üniversitesi Ĕgitim Fakültesi Dergisi, 31(1), 81-91.
[31] Ünsar, S., Kostak, M. A., Kurt, S., \& Erol, Ö. (2011). Hemşirelerin kendini gerçekleştirme düzeyleri ve etlileyen etmenler. Dokuz Eylül Üniversitesi Hemşirelik Yüksekokulu Elektronik Dergisi, 4(1), 2-6.

[32] Van den Broeck, A., Vansteenkiste, M., De Witte, H., \& Lens, W. (2008). Explaining the relationships between job characteristics, burnout, and engagement: The role of basic psychological need satisfaction. Work \& Stress, 22(3), 277-294.

[33] Wigfield, A., \& Eccles, J. S. (1992). The development of achievement task values: A theoretical analysis. Developmental review, 12(3), 265-310.

[34] Wigfield, A., \& Eccles, J. S. (2000). Expectancy-value theory of achievement motivation. Contemporary educational psychology, 25(1), 68-81. 